\title{
Burnout Syndrome: \\ a study with professors at a public university in Maranhão
}

Ester Eliane Jeunon

Doutora em Psicologia Social, do Trabalho e das Organizações pela Universidade de Brasília. Professora Titular do Mestrado Profissional em Administração da FPL Educacional (Fundação Pedro Leopoldo/MG), Minas Gerais, Brasil ester.jeunon@fpl.edu.br

Luís Álvaro dos Santos Correa

Mestre Profissional em Administração pela FPL Educacional (Fundação Pedro Leopoldo/MG).Coordenador de Programas Especiais da Fundação de Apoio ao Ensino, Pesquisa e Extensão - FAPEAD, Minas Gerais, Brasil luisfapead@gmail.com

Leonora da Cunha Duarte Mestranda Profissional em Administração pela FPL Educacional (Fundação Pedro Leopoldo/MG).Professora Convidada do IEC PUC Minas, Minas Gerais, Brasil] leonoracduarte@gmail.com

Eloisa Helena Rodrigues Guimarães

Graduada em letras, mestrado em letras pela Universidade Federal de Minas Gerais, Doutorado em linguística pela Universidade Federal de Minas Gerais. Professora titular da Fundação Pedro Leopoldo

eloisa.guimaraes@fpl.edu.br

Editor Científico: José Edson Lara

Organização Comitê Científico

Double Blind Review pelo SEER/OJS

Recebido em 10.08.2017

Aprovado em 21.08.2017

Este trabalho foi licenciado com uma Licença Creative Commons - Atribuição - Não Comercial 3.0 Brasil 


\section{Abstract}

This report refers to a study that dealt with the prevalence of Burnout Syndrome and the predictive factors associated with it in a Higher Education Institution. The researched phenomenon is a special type of occupational stress characterized by deep feelings of frustration and exhaustion about work performing. A descriptive research was carried out, through a qualitative and quantitative approach, with the institution professors, using a field research as collecting data method with a sociodemographic questionnaire and the Maslach Burnout Inventory. The results showed that $99.4 \%$ of the sample had an average lower than the standard for Burnout prevalence and they also revealed low average concerning Emotional Exhaustion and Personality Loss. Among professors in the health field, it was observed a higher average result concerning Professional Accomplishment. The study showed that at the institution there wasn't burnout prevalence, despite of isolated cases of Emotion Exhaustion, which require preventive and coping measures.

Keywords: Burnout Syndrome, Professors, Risk Factors.

\section{Síndrome de Burnout: um estudo com docentes em uma universidade pública do Maranhão}

\section{Resumo}

Este relato refere-se a um estudo que tratou da prevalência da Síndrome de Burnout e dos fatores preditores a ela associados em uma Instituição de Ensino Superior. O fenômeno pesquisado é um tipo especial de estresse ocupacional caracterizado por profundo sentimento de frustração e exaustão sobre o trabalho desempenhado. Realizou-se pesquisa descritiva, com abordagem quantitativa e qualitativa com os docentes da instituição, tendo como método de coleta de dados a pesquisa de campo, por meio de questionário sócio-demográfico e do Maslach Burnout Inventory. Os resultados mostraram que $99,4 \%$ dos respondentes apresentaram média inferior à padrão para prevalência da Burnout, como também revelaram ser baixa a média de Exaustão e Despersonalização. Entre os professores da área de saúde, observou-se que a média para Realização Profissional foi mais alta. $O$ estudo mostrou que na instituição não houve prevalência da Burnout, apesar de casos isolados de Exaustão Emocional, requerendo medidas preventivas e enfrentamento.

Palavras-chave: Síndrome de Burnout, Docentes, Fatores de Risco. 


\section{Síndrome de Burnout: un estudio con docentes en una universidad pública de Maranhão}

\section{Resumen}

Este relato se refiere a un estudio que trató de la prevalencia del Síndrome de Burnout y de los factores predictores a ella asociados en una Institución de Enseñanza Superior. El fenómeno investigado es un tipo especial de estrés ocupacional caracterizado por un profundo sentimiento de frustración y agotamiento sobre el trabajo desempeñado. Se realizó una investigación descriptiva, con abordaje cuantitativo y cualitativo con los docentes, teniendo como método de recolección de datos la investigación de campo, a través de cuestionario sociodemográfico y del Maslach Burnout Inventory. Los resultados mostraron que el $99,4 \%$ de los encuestados presentaron un promedio inferior al estándar para la prevalencia de Burnout, como también revelaron que era baja la media de Agotamiento y Despersonalización. Entre los profesores del área de salud, se observó que la media para Realización Profesional fue más alta. El estudio mostró que en la institución no hubo prevalencia de la Burnout, a pesar de casos aislados de Agotamiento Emocional, requiriendo medidas preventivas y enfrentamiento.

Palabras clave: Síndrome de Burnout, Docentes, Factores de Riesgo.

\section{Introduction}

Teaching is a generally highly stressful activity with clear repercussions on the physical, mental health and professional performance of professors who are at constant risk of developing Burnout Syndrome (BS).

For Harrison (1999), BS is the result of a chronic stress, typical of the everyday working world. The phenomenon is basically social and expresses the crisis era and disorientation of the current society, affecting strongly the most critical sectors of work, such as assistance jobs, for example, teaching activities.

This is a special type of occupational stress that is characterized by a deep sense of frustration and exhaustion in relation to the performed work, a feeling that can gradually extend to all areas of a person's life. Consequently, it's possible to observe changes in behavior, physical exhaustion, isolation, dizziness tremors and loss of interest in work (Benevides-Pereira, 2010; Carlotto, 2011).

The theme has acquired increasing relevance and concern by professionals, institutional managers, unions and governmental entities. In this sense, it is necessary to expand Burnout studies in university professors, not only in the 
international research agenda, but also in the national one, giving greater importance to the theme, considering its important social repercussion.

In this context, this study aimed to analyze the prevalence of BS and its associated risk factors for professors of a public Higher Education Institution (HEI) in Maranhão.

The importance of this theme study for researches in Administration is justified by the concern of the managers with the sickness of the work teams and by the necessity of the creating methods to reduce the people withdrawal from their work activities.

This report is structured in sessions that contain: the literature review that allows the problem framing from a theoretical point of view; the methodology that describes the types of research and approaches adopted; presentation of the results obtained and their analysis; and the most relevant conclusions presented in the original research.

\section{Literature Review}

The theoretical approach deals with BS, with a brief introduction, based on the research carried out, covering the main aspects of teaching work.

\subsection{Burnout Syndrome and Teaching Work}

According to Carlotto (2002), the teaching activity had its beginning in the sixteenth century under the tutelage of the Church. This institution 'opened itself' to the popular layer to enbable people for reading the sacred scriptures, with the clergy itself responsible for the teaching task. The need to invoke lay collaborators made possible a profession of faith and an oath of fidelity to the principles of the Church, which gave rise to the term professor: a person who professes faith and fidelity of the principles of the institution and donates himself priestly to the students. Over time, several elements were incorporated into the teaching work: curriculum, pedagogical techniques, habilitation, increasingly requiring the professional to become a 
specialist, previously attached to the Church, and now, to the State, the two mediators of the teaching profession.

As Cruz and Lemos (2005) state, universities are centers for the production and diffusion of knowledge, which underlies the professional and personal training of future workers and hence the development of social organization. And just like the other institutions, they require from the professors work organization that involves the distribution of disciplines, workload, teaching plans, semester or annual, interrelationships (teacher-teacher, teacher-student, teacher-director, teachercoordinator, teacher-administrative staff, etc.), as well as meetings through a call for decision-making regarding the follow-up of the teaching-learning process (Carlotto, 2002).

Professors are hired to carry out prescribed activities such as giving classes, research guidelines and readings, and monitor student development with the aim of evaluating them at a given time. For this, professors are obliged to develop certain skills that involve criticism, self-criticism and responsibility requiring intellectual and physical abilities from him or her (Cruz \& Lemos, 2005). The teacher, in addition to teaching, should participate in school management and planning, which means a broader dedication, which extends to families and the community.

According to the mentioned authors, all work is composed of loads, which in the case of professors, we can observe the division into slopes:

- Physical load: is defined as the requirement that has external materiality that changes in the interaction with the body, that is, environmental interactions.

- Psychic load: are psychological dispositions that acquire materiality in the body itself and express themselves through it; are emotional reactions and influence directly and indirectly on the health and life of teachers.

Recent research shows that some of the professionals coexist with pain resulting from overwork and emotional exhaustion, a condition that puts them on the list of those at great risk of acquiring BS. It is the chronification of a state of intense occupational stress, combined with emotional exhaustion, depersonalization (indifference towards the other) and feeling of low professional achievement. A state of great suffering and that has negative implications for the workspace.

If the organization of work is rigid, unchanging, it can cause an increase in the psychic load, becoming a source of tension and suffering, which can lead the worker to become ill. Suffering can be intensified when rigid work organization does not 
allow negotiation between prescribed and actual work. The prescribed work is imposed on the worker, composed of rules and norms, being exactly what must must be done, that is, a determined operative mode. The real work is what is actually executed, contemplating adjustments and techniques used by the worker to perform his or her tasks. The prescribed organization tends to diminish the spaces of participation of the worker, preventing the expression of their subjectivity and creativity, which can generate suffering at work (Maximo, Cançado \& Jeunon, 2012). This is the environment in which the phenomenon of BS arises.

Burnout is the term used by researchers to indicate the process of psychological exhaustion experienced by the worker in relation to his work. At the origin of the word, it means that which ceased to function due to absolute lack of energy, that is, the one that reached its limit, with great loss in its physical and / or mental performance (Trigo, Teng \& Hallak, 2007).

There are several causes for the appearance of BS, such as work stress, high workload, direct contact with people, pressure for productivity, perfectionist personality, high expectation of the future professional, among others. For Maslach, Shaufeli and Leiter (2001), Burnout is a psychosocial phenomenon that emerges as a chronic response to interpersonal stressors occurring in work situations, being composed of three dimensions that are independent (emotional exhaustion, depersonalization and low professional achievement). Emotional exhaustion is characterized by decreased energy, enthusiasm, and feelings of resource depletion. Depersonalization causes the worker to treat his clients, colleagues, and organization as objects. In the low professional achievement, the worker tends to self-evaluate in a negative way and is usually unhappy or unsatisfied with his professional development.

Another relevant aspect for the worsening of the quality of the teaching environment, which can impact on work stress, refers to the occurrence of harassment situations. According to Rodrigues and De Freitas (2014), the multiplicity of roles played by professors may represent a determining factor in his or her exposure to harassment, not only in the classroom, but also in academic orientation tasks, for example. According to Lima, Bishop, Gonçalves and Coelho (2014), the phenomenon of moral harassment is usually evaluated only from the perspective and allegations of the victim, however, it is urgent to take an analytical look at the 
behavior of the aggressors. Therefore, it is up to the organizations to know how to treat concrete situations of harassment within the scope of the alleged harasser, through the adoption of actions to guide and raise awareness of the aggressor.

Benevides-Pereira (2002) characterizes BS by the presence of physical, psychic, behavioral and defensive symptoms.

- Physical symptoms: feeling of constant and progressive fatigue; sleep disturbances; headache; myalgias and arthralgias; migraines; gastrointestinal disorders; immunodeficiency; cardiovascular disorders; changes in the respiratory system; sexual dysfunctions and menstrual changes in women.

- Psychic symptoms: lack of attention and concentration; memory changes; slowness of thought; feeling of alienation, loneliness, insufficiency; impatience; discouragement; dysphoria; depression; mistrust and paranoia.

- Behavioral symptoms: Absence or excess of scruples; irritability; Increased aggressiveness; Inability to relax; Difficulty accepting changes; Loss of initiative; Increased use of substances; High risk behavior and increased suicide probability.

- Defensive symptoms: tendency towards isolation; feeling of omnipotence; loss of interest in work or leisure; insomnia and cynicism.

The physical symptoms mentioned above were also verified by Pego, Zille and Soares (2016) in a study on occupational stress. The symptoms which had higher frequency and intensity in the investigated group were fatigue, nervousness and pain in the muscles of the neck and shoulders, followed by irritability and anguish.

Burnout is a social construct that arises as a consequence of interpersonal and organizational relationships, whereas depression is a set of emotions and cognitions that has consequences on interpersonal relationships. The negative feelings are directed to the triggers of the installation process of BS, that is, the co-workers, later the friends and the relatives and finally the worker itself.

Dejours and Deranty (2010) point to a decrease in the quality of work due to poor service, wrong procedures, negligence and recklessness. The psychological and physical abandonment of work entails the loss of time and money for the worker and for the institution, which has its production compromised. There may be distancing between the individual and their family, children and spouse. Poorly cared clients bear emotional, physical, and financial losses that can extend to family members and even their work environment, thus creating a vicious circle. 
When dissatisfaction is discussed, it's important to point out that, according to Araújo, Miranda e Pereira (2017), as the number of years of experience increases, there is an increase in the satisfaction perceived by the professors. It means the first professional phase has lower levels of satisfaction and the last phase presents the highest levels. Given that, it's possible to conclude that the first phase is critical and that it requires care.

The concept of education has taken on new configurations, where teaching is a commodity and the market regulates all relations. In the case of teaching at the higher education level, this is characterized as a complex activity from the political, social, intellectual, psychological and pedagogical point of view. Moreno-Jiménez, Garrosa, Rodríguez, Martínez and Ferrer (2010) show that university professors constitute a labor category with some specificities, since they work with academic, research and management activities in a very varied proportion. Although it has, like other professions, a controlled productivity component, its activities are differentiated by the character of self-organization and the high intrinsic motivation. It is in this confusing environment in which the professor lives, that he or she moves and must maintain serenity for his or her task of educating, transmitting values, projecting society for the future.

\section{Methodology}

In order to reach the study objective, a descriptive type research was carried out using a qualitative and quantitative approach, using a field research method. The population evaluated consisted of 309 professors who make up the list of specialists, masters and doctors in the Exact, Health, Social, Human, Technological and Biological areas of an HEl in São Luís city (Maranhão State).

Data were collected from a socio-demographic questionnaire (SDQ) consisting of 13 questions, divided into two parts, the first one with personal information and the second one related to labor activities (quantitative aspects). In addition, the instrument contained a question about the sources of stress perceived by them and they were encouraged to respond (qualitative aspects). These data were used to know the profile and performance of these professionals of this IES, trying to verify if 
there is a relation of the variables in the development of BS in the professors participating in the research.

Data collection was also done by an MBI-ES (Maslach Burnout InventoryEducators Survey), adapted for Brazil by Mazon, Carlotto and Câmara (2008), to evaluate the presence or absence of BS. It is a questionnaire composed of 22 questions using a Likert 7 scale that evaluates how professors experience their work, according to three dimensions established by the Maslach model: emotional exhaustion, depersonalization and low professional achievement. All items answered were evaluated using the Likert 7 scale, ranging from 0 to $6,(0=$ never $/ 1=$ once a year or less $/ 2=$ once a month or less $/ 3=$ a few times a month $/ 4=$ once a week $/$ $5=\mathrm{a}$ few times a week), as shown in Table 1.

\section{Table 1}

MBI-ES questionnaire

Rated items

EMOTIONAL EXHAUSTION

\section{Rated matters}

1- I feel tired at the end of a working day.

2- I feel that I have reached the limit of my possibilities.

3- I feel emotionally exhausted by my work.

4- I feel frustrated in my work.

5- Working directly with people causes me stress.

6- My work leaves me exhausted.

7- I feel that I am working too much.

8- When I get up in the morning and go to another working day, I feel tired.

9- Working with people all day requires a lot of effort.

DEPERSONALIZATION 1-I feel that the students blame me for some of their problems.

2 - I believe that I treat some students as if they were impersonal objects.

3- I have become more insensitive to people since I do this work.

4. I am worried that this work is hardening me emotionally.

5 . I do not really worry about what happens to some of the students I attend.
PROFESSIONAL

ACHIEVEMENT

\section{1 - I feel very vital.}

2- I feel stimulated after working in contact with the students.

3-I feel that I can adequately treat emotional problems in my work.

4- I can easily create a relaxed atmosphere for my students.

5. I feel that I positively influence the lives of others through my work.

6 - Read effectively with students' problems.

7- I can easily understand what my students feel.

8- I have achieved many achievements in my profession.

Source: Moreno-Jiménez et al., 2002.

The statistical software SPSS (Statistical Package for the Social Sciences) was used for statistical analysis of the data. The averages, frequencies and standard deviation were calculated. Parametric statistical tests of $t$ student and analysis of variance (ANOVA) were used to compare the avarages. The Pearson correlation test 
was used to measure the correlation between the three dimensions of BS and the quantitative variables, and the results were considered statistically significant when the $p$ value was equal to or less than 0.05. To evaluate the predictors of BS Multiple Linear Regression analysis was used (Stepwise method), considering the dimensions of BS as the dependent variable and the other (socio-demographic, labor and psychosocial) as independent variables.

\section{Results and Analysis}

The obtained results and their respective analysis are presented in five sections: the socio-demographic-labor profile, predictors / psychosocial factors, the prevalence of BURNOUT SYNDROME, the relation between dimensions of Burnout and areas of expertise and coping strategies.

\subsection{Socio-demographic-labor Profile}

Table 2 shows the socio-demographic-labor variables at the HEI.

Table 2

Characterization of the socio-demographic sample

\begin{tabular}{llll} 
Variable & Level & Frequency & $\%$ \\
Genre & Male & 210 & 67.96 \\
& Female & 99 & 32.04 \\
\hline Marital Status & Single & 81 & 26.21 \\
& Married & 209 & 67.64 \\
& Unmarried & 19 & 6.15 \\
\hline Children & Yes & 223 & 72.17 \\
& No & 86 & 27.83 \\
\hline Expertise Areas & Health Science & 41 & 13.27 \\
& Exact Science & 105 & 33.98 \\
& Technological Science & 74 & 23.95 \\
& Social Science & 89 & 28.80 \\
\hline Qualification & Specialization & 15 & 4.85 \\
& Master & 112 & 36.25 \\
& Doctorate degree & 182 & 58.90 \\
\hline Wage & $1,085.00$ a 1734 & 3 & 1.0 \\
(in Brazilian currency) & $7,475.00$ & 144 & 46.6 \\
& 9,745 & 101 & 32.70 \\
& $+9,745$ & 61 & 19.70 \\
\hline Weekly workload & 20 & 80 & 25.90 \\
& 40 & 229 & 74.10 \\
\hline
\end{tabular}

Source: Research data (2017). 
According to the data collected in the SDQ, the research presents a differential on the gender / sex factor, since one of the objectives of this study is to identify sociodemographic factors associated with the syndrome. Regarding marital status, the results show that, even in a world context where many give up getting married, marriage is a firm institution among them. In addition, the vast majority of respondents have children, showing that motherhood or paternity is important to them, even if it is not planned. However, it can not be determined that the marital status of these professors or having children is a risk factor for the syndrome. The area of teaching and titling can have an impact by generating a high quantitative and qualitative demand in the effort, as well as conflict between personal and institutional values, which can lead to the risk factor of BS. Regarding salary satisfaction, the vast majority of the university professors of the HEI surveyed are reasonably satisfied with their salaries, and this factor does not correspond to a risk. On the last variable, the respondents most likely to develop the BS, according to the variable working hours, are the professors of exclusive dedication regime, $74.10 \%$, since they are many hours of work per day, at about eight.

\subsection{Predictors and Psychosocial Factors}

To be considered in Burnout state, the individual must present high scores on emotional exhaustion and depersonalization and low scores on professional achievement. The results showed low levels of exhaustion (2.30), depersonalization (2.00) and high levels of professional achievement, according to Table 3.

\section{Table 3}

Predictors and Psychosocial Factors data

\begin{tabular}{llllll}
\hline Variáveis & N & Min & Max & A & SD \\
\hline Emotional Exhaustion & 309 & 1.00 & 4.67 & 2.30 & 0.48 \\
Depersonalization & 309 & 1.00 & 4.20 & 2.00 & 0.53 \\
Professional Achievement & 309 & 2.25 & 5.00 & 3.51 & 0.48 \\
Paper Conflict & 309 & 0.00 & 3.40 & 1.54 & 0.64 \\
Work overload & 309 & 0.33 & 4.00 & 1.67 & 0.46 \\
Social Support & 309 & 0.57 & 4.00 & 2.37 & 0.62 \\
Interpersonal Conflicts & 309 & 0.00 & 3.50 & 1.03 & 0.50 \\
Autonomy & 309 & 0.80 & 4.00 & 2.70 & 0.61 \\
Job Satisfaction & 309 & 0.50 & 3.50 & 2.26 & 0.51 \\
\hline
\end{tabular}

Source: Research data (2017). 
According to the results obtained, it was verified the low predisposition of these professionals to BS. However, it deserves attention those $2 \%$ of the participants who showed considerable levels of exhaustion with the profession. Therefore, even if the majority of these professionals show low burnout, it is not discarded, the predisposition of the latter to develop it.

With regard to Emotional Exhaustion (2.30), this factor presented a low average compared to other dimensions, revealing that a good one on the part of the professors of this institution are not tired with their work activity.

Regarding depersonalization, the professionals presented an average of 2.00 $(S D=0.53)$ for this factor, and 306 professors showed low levels for this dimension. However, it was verified that $3 \%$ of this total, evidenced high values for this category. This result is worthy of attention, since this expresses a moderate emotional distancing. In this case, the professors of this HEI probably suffer or are presenting negative feelings with respect to colleagues of profession, the institution itself and with the students, leading to a distancing by treating them in a cold and impersonal way (Carlotto, 2002).

Concerning Professional Realization, 258 professors presented moderate levels for this category with an average of (3.51). Of this total, 52 participants expressed low levels for this dimension. This result revealed how much these professionals face their work environment despite the various activities and the contact with several people. Professors who have indicated they are satisfied with their profession probably have invested in their careers, receive better salaries, have better working conditions, and in turn, carry out their activities successfully. Even so, there is a tendency for professors with higher degrees to demonstrate low levels of professional achievement due to the pressures related to overwork, lack of time to meet deadlines and constant competitiveness in the work environment.

In relation to the variable autonomy $(2,70)$, it was verified that, when it increases, the greater the feeling of illusion with the work. This may explain why teachers express feelings of satisfaction with work. As teachers develop their activities with an adequate workload, they perform and carry out their work by making their own decisions with a tendency to gain recognition. And when this recognition comes through higher wages, for example, the greater the degree of satisfaction with work activity. However, the degree of satisfaction is not only related to better salaries, 
but also to other indicators such as the experience acquired with their students, a good relationship between them and a good lesson. In addition to the ability to develop multiple skills with autonomy, satisfaction reinforces the professional's commitment to work and protects against BS.

With regard to social support (2.37), it was observed that most professors are married and have children and this has contributed to face the difficulties in the work. As they receive support from their spouse and their children, they feel loved and valued. This helps minimize emotional distress and increases their self-esteem. In this case, the professors are able to face their problems and solve them calmly and this enables them to reach goals. In addition, the support received from their colleagues and from the HEl should be an important factor in the prevention of workrelated diseases and are a protective factor in developing BS. Otherwise, it increases the chance of these professionals developing the syndrome.

\subsection{Burnout Prevalence}

Table 4 shows an analysis of the prevalence of Burnout dimensions, with low scores for Emotional Exhaustion (EE) and Depersonalization (DE) in the total population. The average is $A<4$, based on the Likert scale. In a reverse direction (because of its positive meaning), the table also shows the results of the dimension related to Professional Achievement (PA).

\section{Table 4}

Burnout Prevalence Values

\begin{tabular}{lllll}
\hline Dimension & $\begin{array}{l}\text { Low } \\
\mathbf{A}<\mathbf{4}\end{array}$ & $\%$ & $\begin{array}{l}\text { High } \\
\mathbf{N}>\mathbf{4}\end{array}$ & $\%$ \\
$\mathrm{NE}$ & 307 & 99.4 & & 2 \\
$\mathrm{NE}$ & 306 & 99 & & 3 \\
$\mathrm{RP}$ & 51 & 16.5 & 258 & 83.5 \\
\hline
\end{tabular}

Source: Research data (2017).

The results showed that about $99 \%$ of the participants did not present high scores for EE and DP, therefore, presenting a higher level of satisfaction for professional achievement. One reason to understand this good result in HEl is sociodemographic-labor factors such as: personal and professional satisfaction, identification with teaching and time of experience. 


\subsection{Relation Between Burnout Dimensions and Areas of Expertise}

The data in Table 5 show that Health Science professors have higher EE, $2.4 \%$, compared to those in the Technological Science (5.6\%). Although the results indicate that these are smaller in relation to the other areas and have a higher EE.

\section{Table 5}

Relation: Burnout Dimensions X Areas of Expertise

\begin{tabular}{llllllll} 
& \multicolumn{3}{c}{ EE } & \multicolumn{3}{c}{ DE } & \multicolumn{3}{c}{ RP } & \\
Variables & $\mathbf{N}$ & $\mathbf{M}$ & $\mathbf{D P}$ & $\mathbf{M}$ & $\mathbf{D P}$ & $\mathbf{M}$ & $\mathbf{D P}$ \\
Health Science & 41 & 2.40 & 0.56 & 1.90 & 0.48 & 3.53 & 0.70 \\
Exact Science & 105 & 2.33 & 0.46 & 2.00 & 0.50 & 3.51 & 0.50 \\
Techonological Science & 74 & 2.17 & 0.46 & 2.00 & 0.70 & 3.52 & 0.57 \\
Social Science & 89 & 2.33 & 0.45 & 2.09 & 0.53 & 3.48 & 0.50 \\
\hline
\end{tabular}

Source: Research data (2017).

Another relevant factor was the area of knowledge (expertise). It was observed that the largest number of participants with BS in the HEI studied is from the Exact area, with the highest percentage corresponding to $34.0 \%$, followed by the Social Sciences professors, with $28.8 \%$. These are acceptable means, if analyzed separately, but they constitute an alert, because if they add up they generate $62.8 \%$ corresponding to a workplace risk factor of occurrence of BS in the institution. Therefore, it's a high percentage, requiring the managers to seek strategies to help such professors if and when diagnosed with the syndrome.

\subsection{Coping Strategies and Suggestions}

Coping refers to any expression, action or behavior that the individual uses to deal with threatening and stressful situations. This concerns Psychology, as it relates to the adaptation of the human being to the different stages of development. The initial definition of coping originated from the psychoanalytic descriptions of the ego defense mechanism which, in the beginning, are primary drives for coping with stress through impulsive behaviors and intrapsychic conflicts (Lazarus \& Folkman, 1991).

In the organizational context, this interaction can happen with a training that aims to subsidize the worker in the choice and construction of healthy coping strategies. When focusing coping on the problem, it includes strategies that affect the work environment and the individual. In order to face possible cases of BS in the HEI, 
it is suggested through Júnior, Guimarães and Jeunon (2014) the management of organizational knowledge, since all types of knowledge require management in order to achieve the desired results. So there is a need to get to know Burnout better by the managers / supervisors and the direction of each department in this HEI. For, managing people also requires social responsibility, and the first step to occur is the respect, transparency, promotion of communication, well-being and internal satisfaction of employees and their dependents, all translated into a healthy organizational structure and environment.

Discussions, lectures, psychological care and group dynamics and motivation, as part of projects that work social responsibility within the work environment, will contribute to the well-being of these professors, as well as pleasant meetings, recognition of honor and merit for their work. It is also important to deal with isolated cases, since this prevents a professor who plays a key role in the HEI to cause embezzlement in the group.

\section{Final Considerations and Conclusions}

This study evaluated the prevalence of Burnout Syndrome (BS) and its associated factors in the teachers of a public HEI in Maranhão State, in Brazil, which results enabled the general view that the occurrence of BS is low in the institution because the data evaluated were below average for the predictive factors of BS.

The characteristics found led to the low prevalence of BS, because the professors, although overwhelmed, do not feel worn to the point of developing the syndrome. Therefore, due to the existence of predisposition to BS in the variables Exhaustion and Overload in the HEl object of the study, it corroborates to the findings of Medeiros and Jeunon (2009), who consider projects as part of strategic planning with short, medium and long-term benefits.

Regarding the limitations of the research, it was observed that the great majority of the professors answered the questionnaire as soon as they delivered, but those who preferred answering at home took more than a week to return. In addition, some of the professors who did not participate in the research and did not submit the questionnaire justified their disability due to personal commitments, lack of time and difficulty In answering a very extensive questionnaire. 
The present work will enable educational institutions to analyze the possible causes of the syndrome in professors in order to mitigate the risks inherent to the phenomenon. Analyzes about the motivating factors and consequences of BS, as well as the socio-demographic-labor profile, enable the application of the research structure to similar institutions. Future research can be intensified with regard to the tangible and intangible costs arising from the phenomenon, aiming at improving the management approaches that can be adopted.

\section{References}

Araújo, T. S., Miranda, G. J., \& Pereira, J. M. (2017). Satisfacion among accounting professor in Brasil. Revista Contabilidade \& Finanças, 28(74), 264-281.

Benevides-Pereira, A. M. T (2010). Burnout: uma tão conhecida desconhecida síndrome. In C. T. Gisele, L. Machado, \& F. P. N. Sobrinho (Orgs.). A Síndrome de Burnout em Professores do Ensino Regular: Pesquisa, Reflexões e Enfrentamento (pp. 39-45). Rio de Janeiro: Cognitiva.

Carlotto, M. S. (2002). A Síndrome de Burnout e o trabalho docente. Revista Psicologia em estudo, 7(1), 21-29.

Carlotto, M. S. (2011). Fatores de Risco da Síndrome de Burnout em técnicos de enfermagem. Revista da Sociedade Brasileira de Psicologia Hospitalar, 14 (2), 726.

Cruz, R. M., \& Lemos, J. C. (2005). Atividade docente, condições de trabalho e processos de saúde. Motrivivência, 24(17), 59-80.

Dejours, C., Deranty, J.P. (2010). The centrality of work. Critical Horizons, 11(2), p.167-180.

Harrison, B. J. (1999). Are you to burn out? Fund Raising Management, 30(3), 25-27.

Lazarus, R. S., \& Folkman, S. (1991). The concept of coping. In Monat, A., \& Lazarus, R. S. (Orgs.). Stress and coping: an anthology (pp. 189-206). New York: Columbia University Press.

Lima, B. A. A. C., Bispo, A. C. K. A., Gonçalves, H. S., \& Coelho, K. S. (2014). Reflexões sobre assédio moral: um estudo à luz da organização pessoense com maior incidência em ações trabalhistas. Revista Gestão \& Tecnologia, 14(1), 201224. 
Maslach, C., Schaufeli, W. B., \& Leiter, M.P. (2001). Job Burnout. Annual Review of Psychology, 52(1), 397-422.

Maximo, J. T. de A., Cançado, V. L., \& Jeunon, E. E.. (2012, setembro). Prazer e Sofrimento no Trabalho: Um Estudo de Caso dos Cirurgiões-Dentistas da Prefeitura de Betim (Relato Técnico). Anais do Encontro da Associação Nacional de Pós-graduação e Pesquisa em Administração, Rio de Janeiro, Brasil, 26.

Mazon, V, Carlotto, M. S., \& Câmara, S. (2008). Síndrome de Burnout e estratégias de enfrentamento em professores. Arquivos Brasileiros de Psicologia, 60(1), 5566.

Medeiros, N.L, \& Jeunon, E. E. (2009). Parceiros para a responsabilidade social: o caso do Projeto brinquedoteca na visão do empresário. Pretexto, 10(1), 49-68.

Moreno-Jiménez, B., Garrosa, E., Rodríguez, R., Martínez, M., \& Ferrer, R. (2010). El Burnout del profesorado universitario y las intenciones de abandono: un estudio multi-muestra. Revista de Psicología del Trabajo y de las Organizaciones, 25(2), 149-163.

Pego, Z. O., Zille, L. P., \& Soares, M. G. (2016). O estresse ocupacional de servidoras técnico-administrativas. Revista Alcance, 23(2), 156-169.

Rocha, E. de A., Jr., Guimarães E. H. R, \& Jeunon, E.E. (2014). A gestão do conhecimento em agência de fomento à pesquisa: proposição de um modelo aplicado. Revista Gestão \& Tecnologia, 14(3), 244-260.

Rodrigues, M., \& De Freitas, M. E. (2014). Assédio moral nas instituições de ensino superior: um estudo sobre as condições organizacionais que favorecem sua ocorrência. Cadernos EBAPE.BR, 12(2), 284-301.

Trigo, T. R., Teng, C. T., \& Hallak, J. E. C. (2007). Síndrome de Burnout ou estafa profissional e os transtornos psiquiátricos. Revista de Psiquiatria Clínica, 34(5), 223-233. 